Cómo citar este artículo: Pardo-Rodríguez, M. L., \& Zorro-Mateus, P. J. P. (2021). Biodegradation of polyvinyl chloride by Mucor s.p. and Penicillium s.p. isolated from soil. Rev.investig.desarro.innov., 11 (2), 387-400.

\title{
Biodegradation of polyvinyl chloride by Mucor s.p. and Penicillium s.p. isolated from soil
}

\section{Biodegradación de policloruro de vinilo por Mucor s.p. y Penicillium s.p. aislados de suelo}

\author{
María Luisa Pardo-Rodríguez ${ }^{1}$ \\ Patricia Joyce Pamela Zorro-Mateus ${ }^{2}$
}

Recibido: septiembre 21 de 2020 Aceptado: diciembre 18 de 2020

\begin{abstract}
PVC is one of the most widely used plastics today and the one that produces the most waste. In recent years, microorganisms capable of degrading it have been reported, most of which come from environments in which PVC is accumulated. The aim of this work was to study the degradation of PVC without plasticizer, from fungi isolated from a soil sample contaminated with PVC resin. The fungi were isolated and morphologically characterized, 30 morphospecies were obtained, 8 were chosen to undergo preliminary tests in a medium whose only carbon source was a PVC film. Growth curves of the two isolates with better results were made and their molecular identification showed that they corresponded to Penicillium sp. and Mucor sp., the latter gained biomass from PVC and in both cases, the films showed visible changes, which were supported by infrared spectra. Although the results shown in this article are preliminary, they open the door to new forms of PVC waste degradation that are very persistent.
\end{abstract}

Keywords: Penicillium expansum, Mucorsp., PVC resin, fungal isolations, growth curves.

\section{Resumen}

El PVC es uno de los plásticos más usados y de los que más residuos se producen. En los últimos años, se han reportado microorganismos capaces de degradarlo y que en su mayoría provienen de ambientes en los que se acumula. El objetivo de este trabajo fue estudiar la degradación del PVC sin plastificante, a partir de hongos aislados de una muestra de suelo contaminada con resina de PVC. Los hongos se aislaron y caracterizaron morfológicamente, obteniendo 30 aislamientos de los que se escogieron 8 para someterlos a pruebas preliminares, en un medio cuya única fuente de carbono era una película de PVC. Se hicieron curvas de crecimiento de los dos aislamientos con mejores resultados, y su identificación molecular mostró que correspondían a Penicillium sp. y Mucor sp.. Este último ganó biomasa a partir del PVC yen los dos casos, las películas mostraron cambios visibles, que fueron respaldados por espectros de infrarrojo. Aunque los resultados mostrados en este artículo son preliminares, abren la puerta a nuevas formas de degradación de los residuos de PVC, que son muy persistentes.

Palabras clave: Penicillium expansum, Mucor sp., PVC, aislamientos fúngicos, curvas de crecimiento.

1 Environmental Engineering Student, Universidad Libre, Bogotá, Colombia. E-mail: marial.pardor@unilibre.edu.co ORCID: https://orcid.org/0000-0002-9484-2318

2 Chemist, Msc. In Biochemistry, Universidad Libre, Bogotá, Colombia. E-mail: patriciap.zorrom@unilibre.edu.co ORCID: https://orcid.org/0000-0001-9017-3914 


\section{Introduction}

Polyvinyl chloride (PVC), is a thermoplastic mainly used in pipes, household implements, furniture, upholstery, disposable products like food and pharmaceutical products packaging and medical devices (Giacomucci, Raddadi, Soccio, Lotti, \& Fava, 2020). Due to its great demand because of its properties, high amounts of waste of this material are generated. It has been estimated that since the beginning of the widespread use of plastic, 6.3 billion tons of these materials have been produced and that roughly $79 \%$ of the waste is disposed of in landfills. This could lead to 2.41 million tons of plastic waste ending up in the oceans annually (Lebreton et al., 2017). Plastic is made to last, so plastic wastes are persistent materials that undergo physical changes by environmental conditions, resulting in very tiny fragments called microplastics, which are currently found both in very populated places as well as remote and unpopulated ones (Bergmann et al., 2019). In Colombia, plastic uptake in 2018 increased by $8.3 \%$ compared to 2017 with 220 thousand tons of PVC resin consumed (Acoplásticos, 2019). This scenario shows the importance of establishing plastic degradation techniques, among other policies, that allow us to reduce plastic wastes.

Incineration is still a conventional way of disposing wastes in some countryside regions, but this PVC-containing waste produces hazardous products when it is heated because it releases free radical molecules, $\mathrm{CO}$, free ions and hydrogen chloride (Vivi, Martins-Franchetti, \& AttiliAngelis, 2019). Although PVC is recalcitrant to biodegradation, there are research reports that showed bacteria and fungi that can degrade this material (Raddadi \& Fava, 2019). Fungi seems a good option, because they have the capacity to degrade organic chemicals with a very low specificity, they are ubiquitous, they can spread fast through mycelial networks and grow at low $\mathrm{pH}$ values (Harms, Schlosser, \& Wick, 2011). In addition, Fungi are able to produce hydrophobins that allows them to attach to hydrophobic substrates, and colonize them, which would be the first step to their degradation (Sánchez, 2020).
Few published studies on the degradation of PVC from fungi are found in the scientific literature. Kirbas, Güner and Keskin (1999), studied the degradation of PVC with the fungal species Pleurotus sp., Poliporus versicolor and Phanerochaete chrysosporium, where the former showed the best results with $19.32 \%$ degradation and $82.15 \%$ decrease in $\mathrm{C}-\mathrm{H}$ bonds, while the latter showed percentages lower than $13.17 \%$. On the other hand, Ali et al. (2014), tested the degradation of PVC films with the fungal species Phanerochaete chrysosporium, Lentinus tigrinus, Aspergillus niger and Aspergillus sydowii, finding changes in the color and deterioration on the analyzed films. In addition, they found a biomass increase in each one of the fungi tested which evidenced the use of PVC as carbon source by fungi. Finally, Sumathi, Viswanath, Lakshmi and SaiGopal (2016), isolated the fungus Cochliobolus sp., from plastic dumped soils and studied the degradation of low molecular weight PVC by laccase enzyme from the fungus. They founded that PVC treated with the fungus was significantly degraded compared with the controls.

The aim of the present work was to study the degradation of PVC films, without plasticizer, by fungi isolated from an environmental sample of soil contaminated with PVC resin. Considering that this soil has been exposed to PVC resin since some decades ago, this could favor the growth of microorganisms capable of degrading the resin. To achieve this objective, fungi were isolated from soil, they were subjected to preliminary tests to look for those that showed some PVC degradation capacity and finally, with best results isolates, we built growth curves.

\section{Materials and methods}

\subsection{Isolation and morphological characterization of fungi}

Samples of soil contaminated with PVC resin, were taken from the ground under a PVC silo in a company that manufactures and markets products of this material in Bogotá, Colombia. The 
resin on the ground was evident in the sampled area. The pits for these samples were $50 \mathrm{~cm}$ deep, distributed in five different spots of the ground of approximately $6 \mathrm{~m}^{2}$ in area, in a zigzag pattern, locating a spot every $3 \mathrm{~m}$. These samples were then mixed, sieved, and homogenized. Ten gr of this soil were mixed with $100 \mathrm{~mL}$ of enrichment medium containing $0.025 \mathrm{~g}$ of $\mathrm{K}_{2} \mathrm{PO}_{4^{\prime}} 0.0625 \mathrm{~g}$ of $\mathrm{MgSO}_{4} \cdot 7 \mathrm{H}_{2} \mathrm{O}, 0.0125 \mathrm{~g}$ of $\mathrm{CaCl}_{2} \cdot 2 \mathrm{H}_{2} \mathrm{O}, 0.0625$ $\mathrm{g}$ of $\mathrm{NH}_{4} \mathrm{NO}_{3}, 0.0125 \mathrm{~g}$ of yeast extract, $1.25 \mathrm{~g}$ of glucose and $1 \mathrm{~g}$ of PVC resin in $1 \mathrm{~L}$ of distilled water. This mixture remained five weeks at $25^{\circ} \mathrm{C}$ and stirred at $150 \mathrm{rpm}$ (Ali et al., 2014).

Serial dilutions of $1 \times 10^{-1}, 1 \times 10^{-2}$ and $1 \times 10^{-3}$ were made; $100 \mu \mathrm{L}$ were taken from each dilution and seeded in triplicate in Czapek, malt extract and PDA culture media. From these media, the fungal morphospecies were picked to isolate them. Subsequently, the macroscopic morphological characterization was performed, according to the appearance of the colonies, and the microscopic characterization was carried out by staining them with lactophenol blue. Observations were performed under a Primo Star ${ }^{\mathrm{T} M}$ Zeiss microscope (Carl Zeiss Microscopy, Jena, Germany) and the Domsch and Gams keys (Domsch K., Gams W \& Anderson, T. 1980) were compared.

\subsection{Preparation of PVC films}

PVC films $(6.2 \times 2.5 \mathrm{~cm})$, were prepared from 0.2 $\mathrm{g}$ of PVC resin and $10 \mathrm{ml}$ of tetrahydrofuran. The films obtained were washed with distilled water and $96 \%$ ethanol for 15 min (Ali et al., 2014). We also investigated if a heat treatment on the PVC films made fungal biodegradation easier, for which, one run was carried out with films heated at $150^{\circ} \mathrm{C}$ for $1 \mathrm{~h}$ (Films C) (De Campos \& Martins Franchetti, 2005), while other run was performed with films without heat treatment (Films SC).

\subsection{Screening of PVC degrading fungi}

From the isolates obtained, eight were chosen for preliminary tests. Clean films with and without heat treatment were incubated with the fungal isolate and $20 \mathrm{ml}$ of minimum salt medium (MSM) with the following composition: $1.0 \mathrm{~g}$ of $\mathrm{K}_{2} \mathrm{HPO}_{4^{\prime}} 0.20 \mathrm{~g}$ of $\mathrm{KH}_{2} \mathrm{PO}_{4^{\prime}} 1.0 \mathrm{~g}$ of $\mathrm{NaCl}$, $0.002 \mathrm{~g}$ of $\mathrm{CaCl}_{2} 2 \mathrm{H}_{2} \mathrm{O}, 0.005 \mathrm{~g}$ of boric acid, $1.0 \mathrm{~g}$ of $\mathrm{NH}_{4} \mathrm{SO}_{4^{\prime}} 0.5 \mathrm{~g}$ of $\mathrm{MgSO}_{4} \cdot 7 \mathrm{H}_{2} \mathrm{O}, 0.001 \mathrm{~g} \mathrm{CuSO}_{4^{\prime}}$ $0.01 \mathrm{~g}$ of $\mathrm{ZnSO}_{4} 7 \mathrm{H}_{2} \mathrm{O}, 0.001 \mathrm{~g}$ of $\mathrm{MnSO}_{4}$ and 0.01 $\mathrm{g}$ of $\mathrm{FeSO}_{4}$ per liter of distilled water (Ali et al., 2014). Tubes with films, MSM and fungi were incubated at $30^{\circ} \mathrm{C}$ and stirred at $150 \mathrm{rpm}$ for 6 weeks. Experiments were performed in triplicate. We carried out two types of controls, one for fungi and another for film. The fungi controls were performed for each isolation tested and consisted of fungus with MMS without film, and the film control consisted of PVC film with MMS without fungus. After incubation, we proceeded to review the macroscopic modifications on the films, observing for changes in color, occurrence of holes and development of microorganisms on the surface (Lucas et al., 2008). In addition, the fungus mass was collected, filtered, dried at $60^{\circ} \mathrm{C}$ for 72 hours and weighed to compare its growth vs. controls (Hamzah, Manikan, \& Abd Aziz, 2017). Also, the spectra of the films were obtained by FTIR at the end of the test and compared with the spectra at the beginning. Finally, the gravimetric weight loss of the PVC films was obtained as follows (Giacomucci, Raddadi, Soccio, Lotti, \& Fava, 2020):

Weight loss (\%) $=$ (initial PVC film weight - final PVC film weight)/ initial PVC film weight ${ }^{*} 100$

\subsection{Molecular identification of the two fungal isolates with better results}

The chosen isolates were sent to the Corpogen corporation where the DNA was extracted and purified using the PowerSoil ${ }^{\circledR}$ DNA Isolation Kit (MO BIO Laboratories Inc.). The Internal Transcribed Spacer (ITS) regions were amplified using the universal primers ITS5 (5'-GGAAGTAAAAGTCGTAACAAGG-3') and ITS4 (5'-TCCTCCGCTTATTGATATGC-3') regions (White, Burns, Lee, \& Taylor, 1990). The PCR conditions were: $5 \mathrm{~min}$. at $95^{\circ} \mathrm{C}$, followed by 35 cycles of $30 \mathrm{~s}$ at $95^{\circ} \mathrm{C}, 30 \mathrm{~s}$ at $55^{\circ} \mathrm{C}$ and $45 \mathrm{~s}$ at $72^{\circ} \mathrm{C}$, followed by 
5 min. at $72^{\circ} \mathrm{C}$. Electrophoresis was carried out to confirm the expected PCR products. Fragments obtained were purified and sequenced by the Sanger method. With the assembled sequences of about $600 \mathrm{bp}$, a preliminary species assignment was carried out based on sequence similarity values of 97 to $100 \%$ against GenBank. With the sequences with the highest \% similarity and those obtained, an alignment was made using the Muscle algorithm, the dendrogram was constructed using Mega X software (Kumar, Stecher, Li, Knyaz, \& Tamura, 2018).

The GenBank accession numbers for the nucleotide sequences obtained in this study, are MT509528 and MT509529.

\subsection{Growth curves}

With the two isolates with better results in the screening test, growth curves were built from monosporic cultures of each isolate, following the same procedure performed for screening test, using PVC films without heating treatment. Data were collected every 7 days for 15 weeks, recording the mass gained by the fungi and the FTIR spectra of each film exposed to the fungal species. Like the screening test, controls were performed by running the test with fungus and MMS without films, and with films and MMS without fungus.

\subsection{Statistical analysis of data}

For the screening tests, an analysis of variance (ANOVA) was initially performed, no significant inequalities were found in the heat treatment tested, so a box plot was made as an alternative to observe the differences between one treatment and another. Non-heated films were chosen to evaluate PVC films degradation in the screening test. In order to assess if there were significant differences in fungal masses and gravimetric weight losses among the fungi tested, we performed one-way ANOVA, followed by a post-hoc Tukey test. For the growth curves, the t-test was used for two samples, assuming equal variances, to show differences between pairs of weeks during the study. Statistically significant results were represented by $p$-values $<0.05$. Statistical analyses were performed using the JMP trial statistical software package, version 15.2.1 (SAS Institute Inc, Cary, NC).

\section{Results and discussion}

\subsection{Isolation and morphological characterization of fungi}

Thirty morphotypes that presented macroscopic differences were isolated. From these, the most morphologically different were chosen and characterized macro and microscopically, comparing their characteristics with the keys of Domsch and Gams. Eight genera were identified: Gliocladium, Streptomyces, Piptocephalis, Tetrachaetum, Sympodiella, Synnematium, Penicillium, and Mucor. Table 1 shows the macro and microscopic characteristics found for each isolate (Domsch et al., 1980; Barnett \& Hunter, 1972; Pacasa-quisbert, Loza-murguia, Bonifacio-flores, Vino-nina, \& Serrano-canaviri, 2017). 
Table 1. Morphological description of the isolated fungal strains.

\begin{tabular}{|c|c|c|c|c|}
\hline \multirow{2}{*}{ Code } & \multirow{2}{*}{ Genus } & \multicolumn{2}{|c|}{ Macroscopic description } & \multirow{2}{*}{ Microscopic description } \\
\hline & & Obverse & Reverse & \\
\hline D3 & Glicocladium & $\begin{array}{l}\text { Fast growing circular colony, } \\
\text { dark brown to black and } \\
\text { cottony in texture. }\end{array}$ & Black & $\begin{array}{l}\text { Hyaline conidiophores, with } \\
\text { branches of penicilate, form- } \\
\text { ing a compact brush. }\end{array}$ \\
\hline $\mathbf{L}$ & Streptomyces & $\begin{array}{l}\text { Cottony irregular colony, } \\
\text { light yellow and white. }\end{array}$ & $\begin{array}{l}\text { Yellow } \\
\text { and white }\end{array}$ & $\begin{array}{l}\text { Tiny spores produced in chains } \\
\text { by segmentation hyphae. }\end{array}$ \\
\hline $\mathbf{W}$ & Piptoceph & $\begin{array}{l}\text { White colony at the beginning, } \\
\text { then yellowish cottony } \\
\text { and orange at the end. }\end{array}$ & Pale pink & Little branched conidiophores \\
\hline $\mathbf{M}$ & Tetrachaetum & $\begin{array}{l}\text { Pink circular colony, with } \\
\text { white filamentous edges. }\end{array}$ & $\begin{array}{l}\text { Yellowish } \\
\text { cream, } \\
\text { white }\end{array}$ & $\begin{array}{l}\text { Simple thin conidiophores } \\
\text { sparsely branched. Apical conid- } \\
\text { ia, hyaline, with long branches } \\
\text { diverging from a common point. }\end{array}$ \\
\hline E10 & Sympodiella & $\begin{array}{l}\text { The colony is spread out in a } \\
\text { cottony, white, and red color. }\end{array}$ & $\begin{array}{l}\text { Light } \\
\text { yellow }\end{array}$ & $\begin{array}{l}\text { Long chains are observed. } \\
\text { Simple, dark, hyaline solitary } \\
\text { conidiophores in unbranched } \\
\text { chains joined laterally, cy- } \\
\text { lindrical with blunt ends. }\end{array}$ \\
\hline $\mathbf{F}$ & Synnematium & $\begin{array}{l}\text { Circular colony, white and pink } \\
\text { on the edges, woolly texture. }\end{array}$ & $\begin{array}{l}\text { Deep } \\
\text { yellow } \\
\text { with } \\
\text { streaks }\end{array}$ & $\begin{array}{l}\text { Hyphae thin tapered to a } \\
\text { pointed tip, hyaline conidia. }\end{array}$ \\
\hline AB & Penicillium & $\begin{array}{l}\text { Green circular colony with } \\
\text { white edge, dusty texture. }\end{array}$ & $\begin{array}{l}\text { Light } \\
\text { yellowish } \\
\text { brown }\end{array}$ & $\begin{array}{l}\text { Conidiophores arising from } \\
\text { individually branched myce- } \\
\text { lium near the apex, hyaline } \\
\text { conidia, most globose or ovoid. }\end{array}$ \\
\hline $\mathbf{Q}$ & Mucor & $\begin{array}{l}\text { Brown circular colony, white at } \\
\text { the center, cottony texture. }\end{array}$ & $\begin{array}{l}\text { Light } \\
\text { brown }\end{array}$ & $\begin{array}{l}\text { Conidiophores in ball } \\
\text { shaped clusters. }\end{array}$ \\
\hline
\end{tabular}

\subsection{Screening of PVC degrading fungi}

To compare the fungal biodegradation in PVC films previously treated with and without heat, a one-way ANOVA was performed and showed that there was no statistical difference between treatments $(P=0.944 ; F=0.0051 ; d f=47)$. In addition, a box-and-whisker plot was built with the data obtained (Figure 1). It shows that there is no significant difference between the mass gained by the fungi from heat-treated PVC film versus fungi from non-heat-treated PVC film, since the medians obtained for both treatments are very similar, as evidenced by the lines inside the boxes. The atypical data is also shown. 


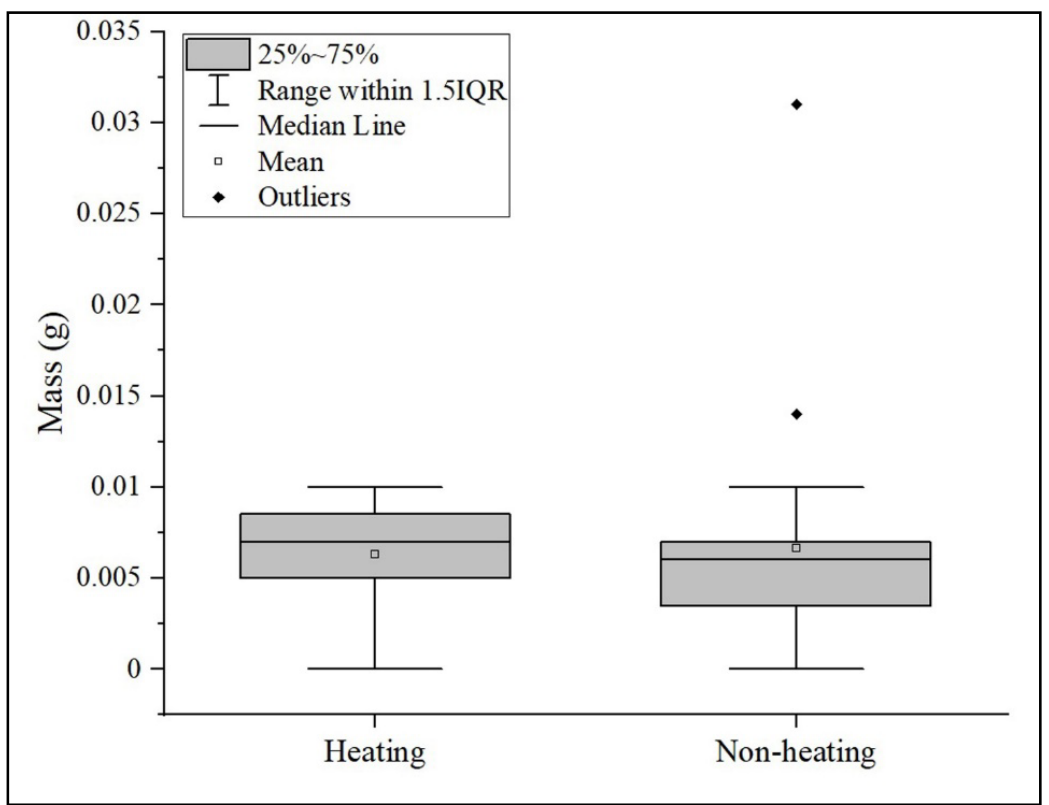

Figure 1. Box and whisker plot for PVC films heated and non-heated before fungal degradation.

For screening test, we evaluated fungal biodegradation by calculating fungal masses (Figure 2) and gravimetric weight loss percentage by PVC films (Figure 3). We obtained results of ANOVA analysis that showed a statistically significant difference among fungal masses ( $p<0.0001$; $\mathrm{F}=51.77 ; \mathrm{df}=15)$ and weight loss percentage $(p<0.0001 ; F=353.54 ; d f=8)$. The best results were exhibited for $A B$ and $Q$ isolates. In fact, Figure 2 shows that both, $A B$ and $Q$ isolates, had a statistically significant increase of biomass compared with their controls $(p<0.05)$. This trend is not evidenced for the other isolates tested.

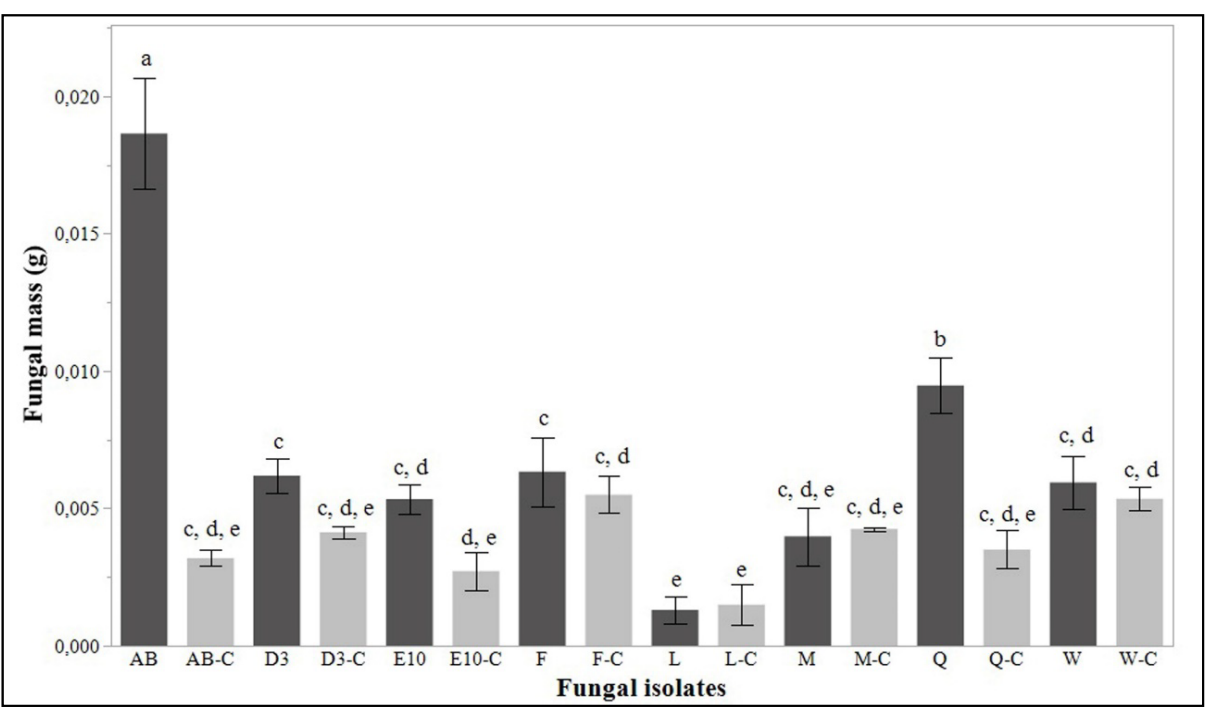

Figure 2. Fungal mass reached in the screening test for the eight isolates analyzed. $C$ letter in fungal isolates is used to differentiate controls run for each isolate. Standard deviation of triplicate measurements is shown as error bars. Letters $a, b, c, d$, e show results of post-hoc analyses and different letters indicate a significant statistical difference in fungal mass value $(p<0.05)$ 


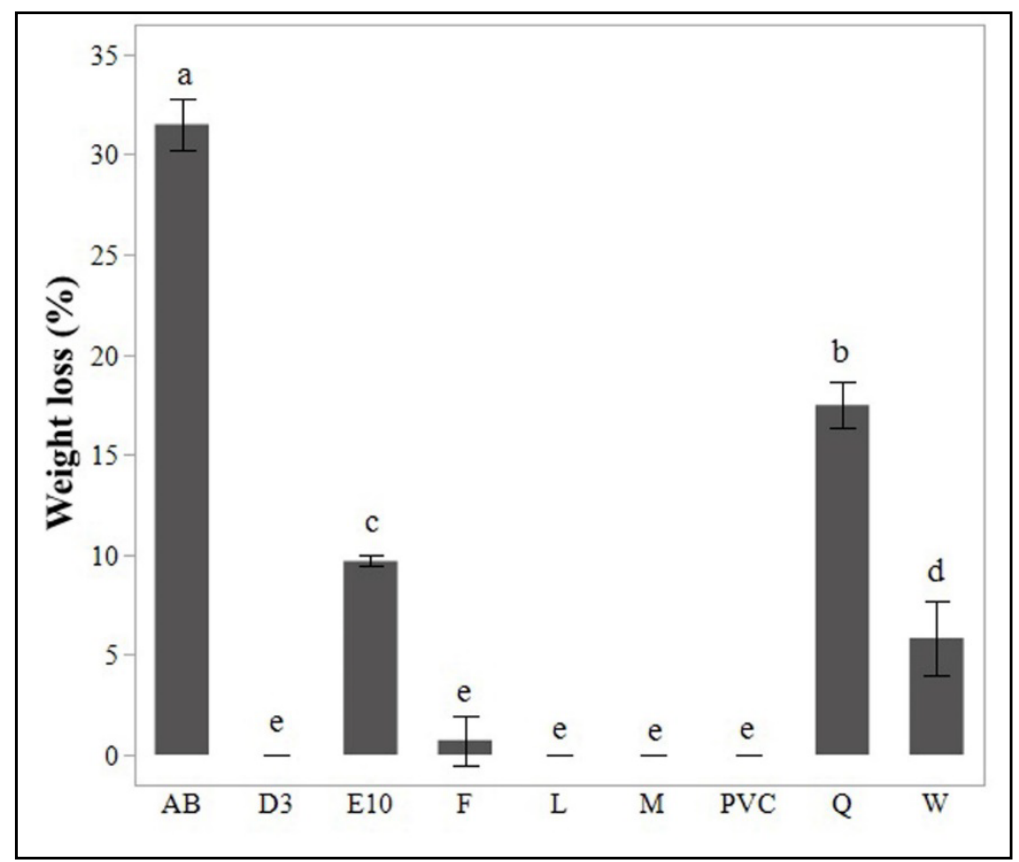

Figure 3. Gravimetric weight loss percentage by PVC films in the screening test for the eight isolates analyzed.

In figure 3, PVC stands for the film used in the control test. Standard deviation of triplicate measurements is shown as error bars. Letters a to e, show results of post-hoc analyses and different letters indicate a significant statistical difference in weight loss value $(p<0.05)$. Figure 3 shows that PVC films from isolates $A B$ and $Q$ also have a statistically significant percentage weight loss compared with the control, which was a PVC film incubated under the same conditions as samples but without fungus $(p<0.05)$. Indeed, we observed that films from these isolates showed much more cracks and opacity compared with the films from other fungi.

FTIR spectra of all the films exposed to fungal isolates were obtained. However, we only include spectra from $Q$ and $A B$ (Figure 4), as they were the best results. The spectrum of the PVC film from a blank test, represented in solid line, shows two strong bands between 3000 and 2900 $\mathrm{cm}^{-1}$ corresponding to $\mathrm{C}-\mathrm{H}$ stretching of $\mathrm{CHCl}$ and $\mathrm{CH}_{2}$. A deformation band of $\mathrm{CH}_{2}$ is found near $1400 \mathrm{~cm}^{-1}$, and two more $\mathrm{C}-\mathrm{H}$ deformation bands of $\mathrm{CHCl}$ are seen between 1350 and 1200 $\mathrm{cm}^{-1}$. Close to $1100 \mathrm{~cm}^{-1}$ there is a C-C stretching band, near $1000 \mathrm{~cm}^{-1}$ is shown a rocking band of $\mathrm{CH}_{2}$ and finally, between 700 and $600 \mathrm{~cm}^{-1}$ there are three $\mathrm{C}-\mathrm{Cl}$ stretching bands (Park, Park, Kim, Canlier, \& Hwang, 2018). PVC film spectra after testing with the $Q$ and $A B$ isolates are observed in dashed lines in Figure 4. The main difference among the spectra from the PVC blank film and the two films from $A B$ and $Q$ treatment, lies in a baseline drop off that is much more remarkable at the left of the spectra from $A B$ and $Q$ isolates. This is explained because of the physical changes in these films, like the observed cracks, which could make the surface rougher causing scattering of the infrared light, that is more visible at greater wavenumbers. Figure 4 also shows the occurrence of a new band near $1700 \mathrm{~cm}^{-1}$ which could be an evidence of polymeric oxidation and hydrolysis. 


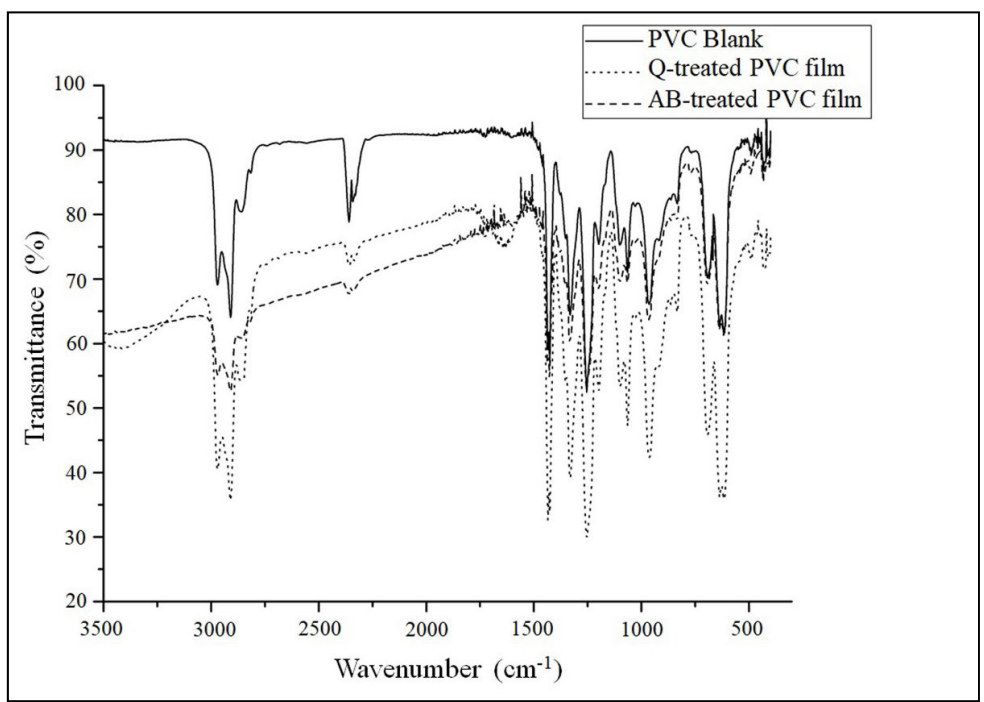

Figure 4. IR spectra of PVC films from screening degradation test with $Q$ and $A B$ fungal isolates.

\subsection{Molecular identification of the two fungal isolates with better results}

Isolates $Q$ and $A B$ showed the best results in the screening test with PVC films, from the morphological characterization, shown in Table 1. We observe that these isolates belong to Mucor and Penicillium genera, respectively. Moreover, we confirmed these results by sequencing the ITS4 and ITS5 of the $18 \mathrm{~S}$ ribosomal gene. The comparison of the obtained sequences with the Genbank databases, showed that the $\mathrm{Q}$ sequence has $99 \%$ similarity with sequences of the genus Mucor sp. The sequence obtained for AB showed $99 \%$ similarity with sequences from Penicillium expansum species. From the results of $\%$ similarity of the sequences compared with the Genbank database; the phylogenetic analysis shown in Figure 5 was carried out.

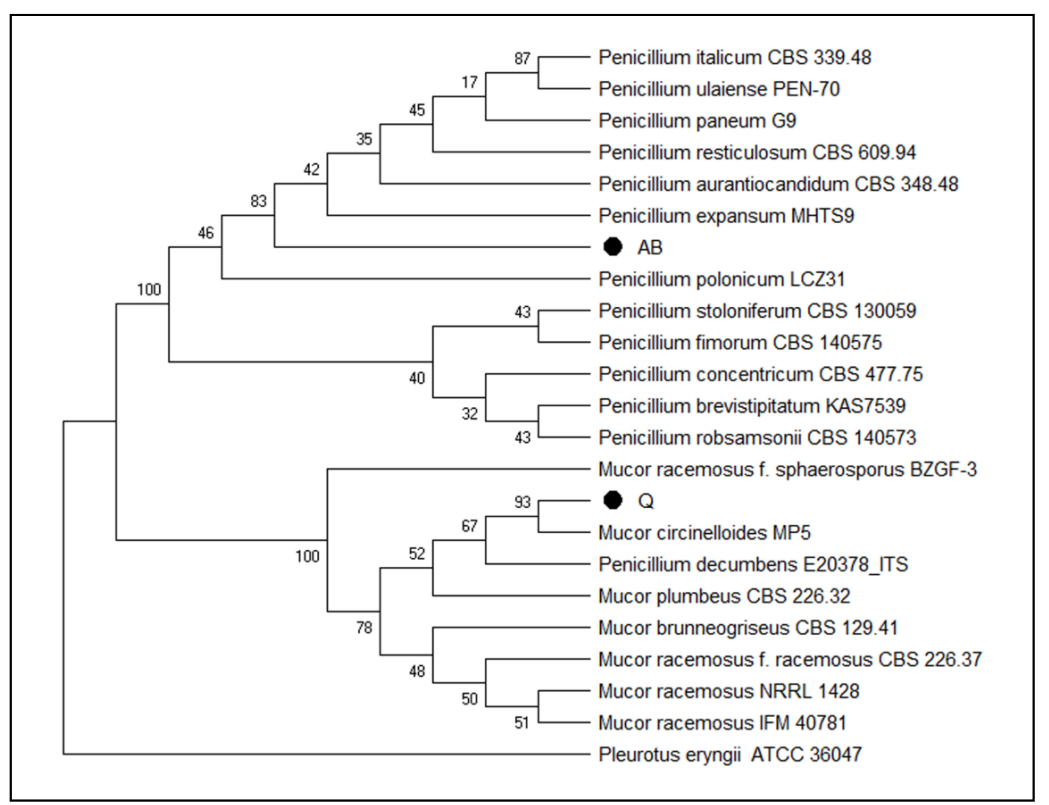

Figure 5. Phylogenetic analysis of $Q$ and $A B$ fungal morphotypes isolated from PVC-contaminated soil. 
In figure 5, dendrogram constructed from the sequences obtained from ITS4 and ITS5 of the $18 \mathrm{~S}$ ribosomal gene using Mega $\mathrm{X}$ (Kumar et al., 2018). Neighbor Joining (Kimura, 1980) was used as clustering algorithm and Kimura 2-parameter (Felsentein, 1985) as distance matrix.
The number of nodes represents the Bootstrap percentage values based on 1000 replicates. Figure 5 also corroborates the morphological characterization presented in Table 1 for isolates $Q$ and $A B$, and the macroscopic appearance of this fungi are shown in Figure 6.
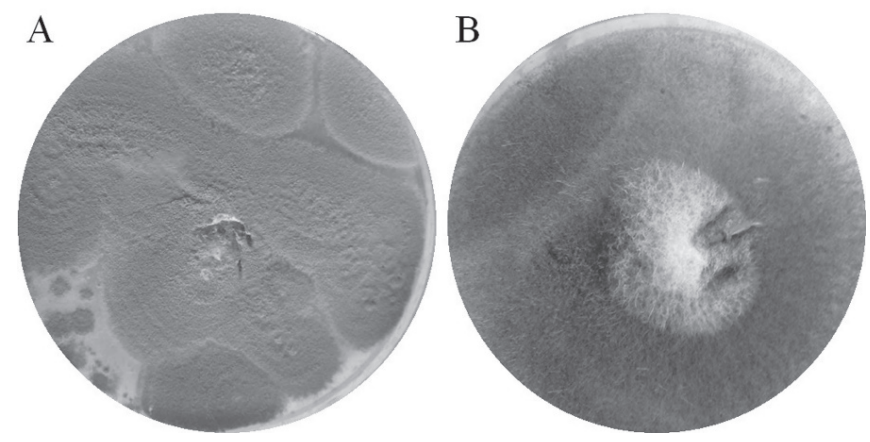

Figure 6. Fungi with best results in screening test. A) shows a macroscopic image of Penicillium expansum, and B) of Mucor sp.

\subsection{Mucor sp., and Penicillium expansum growth curves}

Figure 7 shows the growth curves results of the two selected morphospecies, Mucor sp., and Penicillium expansum. To evidence that fungus masses among weeks were statistically different, a one-way ANOVA analysis was performed, and difference between one week and another was checked by the t test for two equal variances. The growth curve for Mucor sp. (ANOVA: $p<0.0001 ; F=79.72 ; d f=15)$, shows that there are not big changes in mass gain in the first nine weeks, although $t$ test showed significant differences in weeks 0 to 1,1 to 2,4 to 5 and 5 to $6(p<0.05)$, these differences could be seen as attempts done for the fungi trying to find an enzymatic way to degrade the PVC films, as it was the only carbon source available in the test culture medium. From week nine, a sustained mass gain is observed until the last week in which the experiment was run (fifteen weeks in total), demonstrating that the process undergone from week 0 to 9 was adaptation to the conditions, and that the fungi finally found an enzymatic way to take advantage of available nutrients, going from the adaptation phase to the logarithmic growth phase.

Regarding mass gain, Ji-Dong Gu (2003) showed that polymers such as PVC have potential substrates for fungi, since these organisms have enzymes such as extracellular and intracellular depolymerases that participate in biological degradation. So, the increase in mass gain of a fungus is related to the action of exoenzymes that decompose polymers, since they produce short chains that can pass the semi-permeable wall and then being used as carbon and energy sources. This process is known as depolymerization (Gu, 2003). 


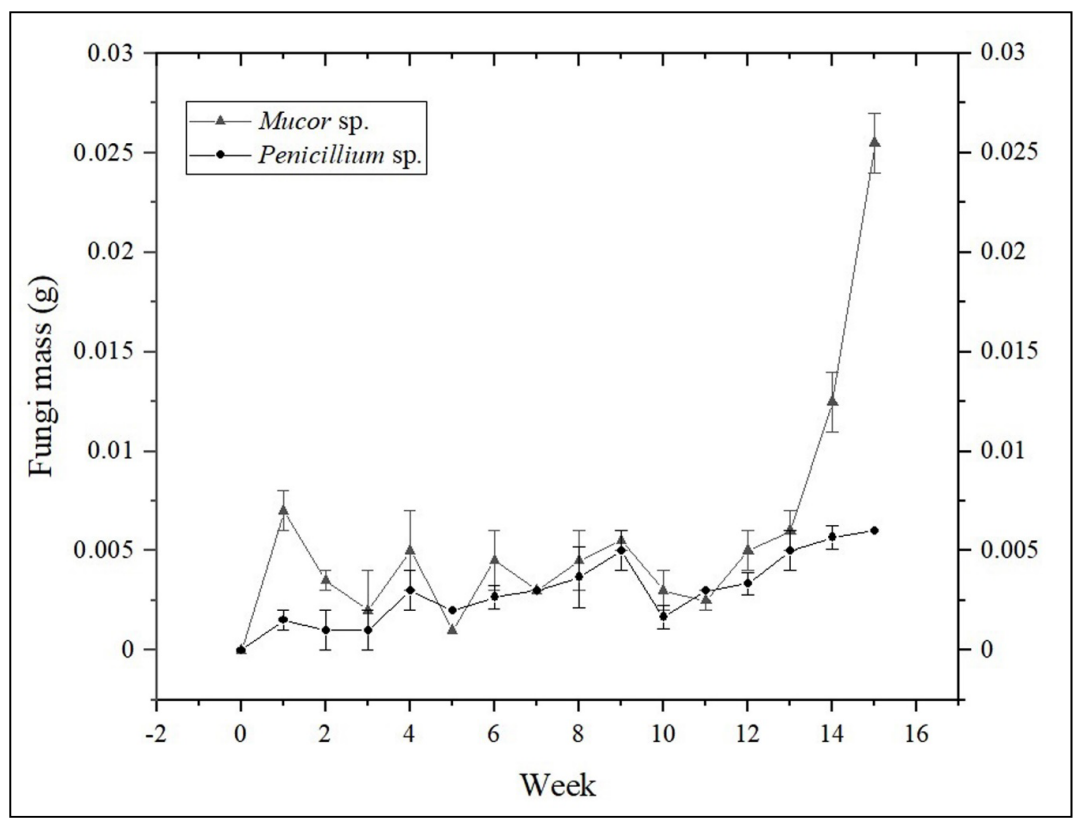

Figure 7. Growth curves for Mucor sp. and Penicillium expansum. Standard deviation of triplicate measurements is shown as error bars.

The growth curve (Figure 7) for Penicillium expansum shows statistically significant differences among weeks (ANOVA: $p<0.0001 ; \mathrm{F}=9.78 ; \mathrm{df}=15$ ). However, $t$ test showed significant differences just in weeks 0 to 1,9 to 10 and 10 to $11(p<0.05)$. Of these pairs of weeks, there is only an appreciable increase in mass in weeks 0 to 1 , thus, this curve shows that the fungi remain in an adaptation phase, that does not achieve a logarithmic phase within the study time (fifteen weeks), in contrast to what was observed with Mucor sp. Although, fungus dry mass does not decrease either in the last weeks, which shows that eventually the fungi would find an enzymatic way to feed on the PVC film if the test were carried out for a longer period (Vrabl, Schinagl, Artmann, Heiss, \& Burgstaller, 2019).

Infrared analysis makes possible to determine changes in the chemical composition of PVC films. In Figure 8, the infrared spectra of PVC films are shown, corresponding to week $15^{\text {th }}$ of the study after the action of the species Mucor sp., and Penicillium expansum. The figure shows a reduction in the peaks between 3000 and 2900 $\mathrm{cm}^{-1}$ corresponding to the $\mathrm{C}-\mathrm{H}$ bond. In addition, the raw spectra for these PVC films, showed a more marked baseline drop off compared with the spectra obtained for the screening test, which is consistent with a longer treatment time that caused more physical changes in the films and a rougher surface that increased the infrared light scattering phenomenon. 


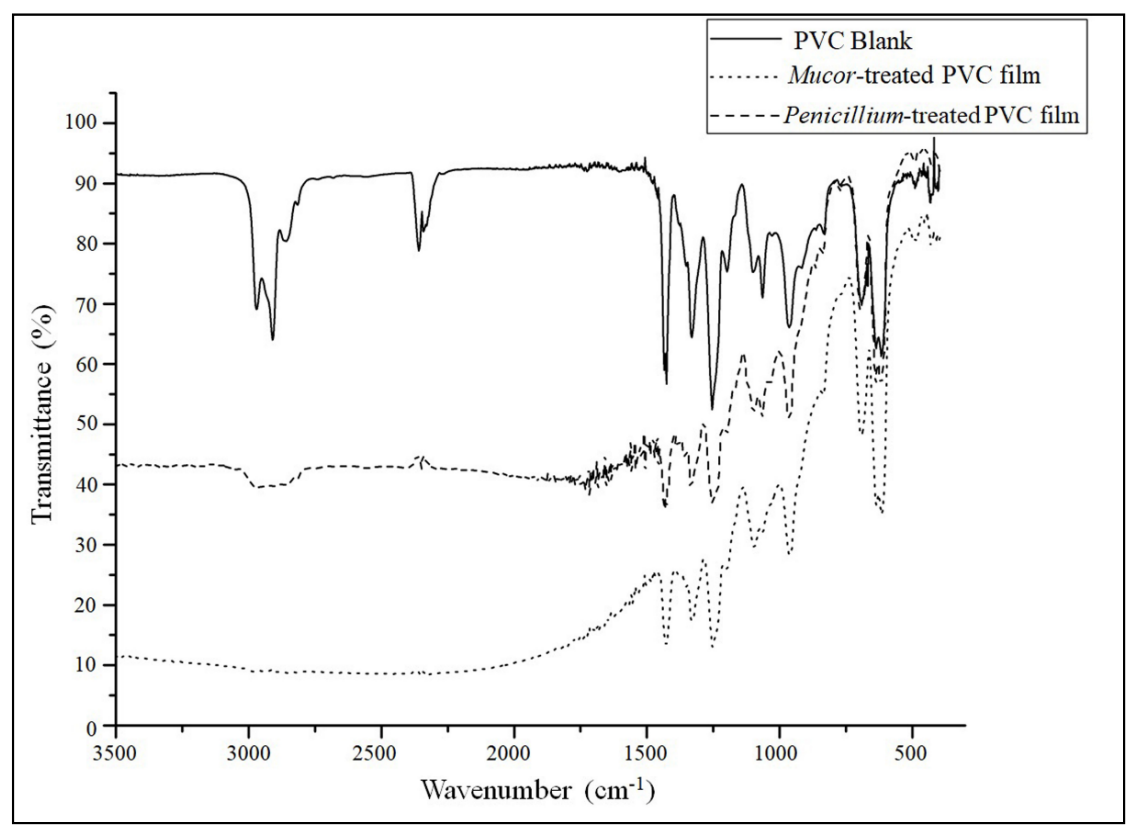

Figure 8. IR spectra obtained from PVC films from $15^{\text {th }}$ week of growth curves for Mucor sp., and Penicillium expansum.

The infrared spectra changes shown in Figure 8 are consistent with the results mentioned on the work published by Kirbas, Guner and Keskin (1999), in which they found degrading action in the fungal species Pleurotus, Poliporus versicolor and Phanerochaete chrysosporium. They found changes in the $\mathrm{C}-\mathrm{H}$ bond with a decrease of $82.15 \%$ measured by FTIR. In addition, Webb et al. (2000) carried out a study of colonization by fungi and biodeterioration of PVC, which included, among other fungal strains, Penicillium glabrum. They found that this fungus produces extracellular esterases that degrade plasticizers and cause the degradation of PVC. In this research, we found two fungi that showed the best results, one of them belonging to genus Penicillium, which could use a similar enzymatic way to take advantage of PVC. Likewise, fungi can degrade PVC by means of a dehydrochlorination process, this reaction was evidenced by Kaczmarek and Bajer (2007). They tested PVC containing cellulose degradation by Trichoderma koningi, Fusarium oxysporu and Penicillium sp., finding significant changes in $\mathrm{C}-\mathrm{Cl}$ bonds peaks on IR spectra. The other fungus found in the present work belongs to the genus Mucor sp. About it, Grisa et al. (2011) carried out studies on the biological degradation of PVC in a sanitary landfill, one of the strains that showed the best results was an isolate of Mucor spp. Similarly, Grisa found important changes in the region of the $\mathrm{C}-\mathrm{H}$ bond of the infrared spectrum as found in the analysis shown above. These works are the few found in the scientific literature that show that PVC degradation capacity has been found in fungi belonging to the genera Penicillium and Mucor, and that fungi from these genera can have an enzymatic battery that allows them to degrade a variety of this polymer bonds.

\section{Conclusions}

Mucor sp., was able to grow from a culture medium with PVC as the only carbon source, which evidences that this fungal strain could take advantage of it. In addition, we obtained the FTIR spectra of PVC films, that demonstrate that the polymer undergoes physical and chemical changes produced by this fungus. Furthermore, Penicillium expansum showed promising results 
in the screening test, but it could not reach the exponential growth phase in the growth curve. However, it did not reach a death phase in the time the experiment was performed, which showed that it could need a longer test time. Although, we found encouraging results, this work requires further study to optimize the growth conditions of the fungi to degrade PVC and to understand the mechanisms used for it, since the biodegradation of PVC seems to be possible. Although there are not many papers published in the literature on the matter, some of these, including this work, show the degrading activity of fungi on this material, which is a promising alternative to manage PVC waste.

\section{Acknowledgements}

The work reports the research project code 21.103,594, to obtain the Grade of Environmental Engineer from the Faculty of Engineering, of the Universidad Libre in Bogotá.

\section{References}

Acoplásticos. (2019). Plásticos en Colombia 20192020. In Plásticos en Colombia 2019-2020 (49th ed.,126).

Ali, M. I., Ahmed, S., Robson, G., Javed, I., Ali, N., Atiq, N., \& Hameed, A. (2014). Isolation and molecular characterization of polyvinyl chloride (PVC) plastic degrading fungal isolates. Journal of Basic Microbiology, 54(1), 18-27. https://doi. org/10.1002/jobm.201200496

Barnett, H., \& Hunter, B. (1972). Illustrated genera of imperfect fungi (Third). Minneapolis: Burgess Publishing Company.

Bergmann, M., Mützel, S., Primpke, S., Tekman, M. B., Trachsel, J., \& Gerdts, G. (2019). White and wonderful? Microplastics prevail in snow from the Alps to the Arctic. Science Advances, 5(8), 1-10. https://doi.org/10.1126/sciadv.aax1157

De Campos, A., \& Martins Franchetti, S. M. (2005). Biotreatment effects in films and blends of PVC/
PCL previously treated with heat. Brazilian Archives of Biology and Technology, 48(2), 235-243. https:// doi.org/10.1590/s1516-89132005000200010

Domsch, K. Gams, W. \& Anderson, T. (1980) Compendium of soil fungi, 1, Academic Press London Ltd. London, United Kingdom.

Felsentein, J. (1985). Confidence limits on phylogenies: An approach using the bootstrap. Evolution, 39 (4), 783-791. https://doi. org/10.2307/2408678

Giacomucci, L., Raddadi, N., Soccio, M., Lotti, N., \& Fava, F. (2020). Biodegradation of polyvinyl chloride plastic films by enriched anaerobic marine consortia. Marine Environmental Research, 158. https://doi.org/10.1016/j.marenvres.2020.104949

Grisa, A. M. C., Simioni, T., Cardoso, V., Zeni, M., Brandalise, R. N., \& Zoppas, B. C. D. A. (2011). Degradação biológica do PVC em aterro sanitário e avaliação microbiológica. Polimeros, 21(3), 210-216. https://doi.org/10.1590/S010414282011005000046

Gu, J.-D. (2003). Microbiological deterioration and degradation of synthetic polymeric materials: Recent research advances. International Biodeterioration and Biodegradation, 52, 69-91. https://doi.org/10.1016/S0964-8305(02)00177-4

Hamzah, A., Manikan, V., \& Abd Aziz, N. A. F. (2017). Biodegradation of tapis crude oil using consortium of bacteria and fungi: Optimization of crude oil concentration and duration of incubation by response surface methodology. Sains Malaysiana, 46(1), 43-50. https://doi. org/10.17576/jsm-2017-4601-06

Harms, H., Schlosser, D., \& Wick, L. Y. (2011). Untapped potential: exploiting fungi in bioremediation of hazardous chemicals. Nature Reviews Microbiology, 9, 177. http://dx.doi.org/10.1038/ nrmicro2519

Kaczmarek, H., \& Bajer, K. (2007). Biodegradation of Plasticized Poly (Vinyl Chloride) Containing Cellulose. Journal of Polymer Science, 45, 903-919. https://doi.org/10.1002/polb 
KIrbas, Z., Keskin, N., \& Güner, A. (1999). Biodegradation of Polyvinylchloride (PVC) by White Rot Fungi. Bull. Environ. Contam. Toxicol, 63, 335-342. https://doi.org/10.1007/s001289900985

Kimura, M. (1980). A simple method for estimating evolutionary rates of base substitutions through comparative studies of nucleotide sequences. Journal of Molecular Evolution, 16(2), 111-120. https://doi.org/10.1007/BF01731581

Kumar, S., Stecher, G., Li, M., Knyaz, C., \& Tamura, K. (2018). MEGA X: Molecular evolutionary genetics analysis across computing platforms. Molecular Biology and Evolution, 35 (6), 1547-1549. https://doi.org/10.1093/molbev/msy096

Lucas, N., Bienaime, C., Belloy, C., Queneudec, M., Silvestre, F., \& Nava-Saucedo, J. E. (2008). Polymer biodegradation: Mechanisms and estimation techniques - A review. Chemosphere, 73(4), 429-442. https://doi.org/10.1016/j.chemosphere.2008.06.064

Pacasa-quisbert, F., Loza-murguia, M., Bonifacioflores, A., Vino-nina, L., \& Serrano-canaviri, T. (2017). Comunidad de hongos filamentosos en suelos del Agroecosistema de K'iphak'iphani, Comunidad Choquenaira-Viacha. Selva Andina Research Society, 8 (1), 2-25. http://www. scielo.org.bo/scielo.php?script=sci_arttext\&pid $=$ S2072-92942017000100002

Park, E. J., Park, B. C., Kim, Y. J., Canlier, A., \& Hwang, T. S. (2018). Elimination and substitution compete during amination of poly(vinyl chloride) with ehtylenediamine: XPS analysis and approach of active site index. Macromolecular Research, 26 (10), 913-923. https://doi.org/10.1007/ s13233-018-6123-z

Raddadi, N., \& Fava, F. (2019). Biodegradation of oil-based plastics in the environment: Existing knowledge and needs of research and innovation. Science of the Total Environment, 679, 148-158. https://doi.org/10.1016/j.scitotenv.2019.04.419

Sánchez, C. (2020). Fungal potential for the degradation of petroleum-based polymers: An overview of macro- and microplastics biodegradation. Biotechnology Advances, 40. https://doi. org/10.1016/j.biotechadv.2019.107501

Sumathi, T., Viswanath, B., Lakshmi, A. S., \& Saigopal, D. V. R. (2016). Production of laccase by Cochliobolus sp. Isolated low molecular weight PVC. Biochemistry Research International, 2016, 1-10. https://doi.org/http://dx.doi. org/10.1155/2016/9519527

Vivi, V. K., Martins-Franchetti, S. M., \& Attili-Angelis, D. (2019). Biodegradation of PCL and PVC: Chaetomium globosum (ATCC 16021) activity. Folia Microbiologica, 64, 1-7. https://doi.org/10.1007/ s12223-018-0621-4

Vrabl, P., Schinagl, C. W., Artmann, D. J., Heiss, B., \& Burgstaller, W. (2019). Fungal Growth in Batch Culture - What We Could Benefit If We Start Looking Closer. Frontiers in Microbiology, 10(October), 1-11. https://doi.org/10.3389/fmicb.2019.02391

Webb, J. S., Nixon, M., Eastwood, I. M., Greenhalgh, M., Robson, G. D., \& Handley, P. S. (2000). Fungal colonization and biodeterioration of plasticized polyvinyl chloride. Applied and Environmental Microbiology, 66(8), 3194-3200. https:// doi.org/10.1128/AEM.66.8.3194-3200.2000

White, T., Burns, T., Lee, S., \& Taylor, J. (1990). Amplification and direct sequencing of fungal ribosomal RNA genes for phylogenetics. In D. H. Gelfand, J. J. Sninsky, \& T. J. White (Eds.), PCR protocols. A guide to methods and applications 18, 315-322). San Diego, Calif.: Academic Press Inc. 